\title{
Expression of adaptation potential by cultivars of highbush blueberry when introduced to Belarusian Polesia
}

\author{
Tatyana $V$. Kurlovich ${ }^{*}$ \\ Central Botanical Garden of NAS, 220012, Minsk, Belarus
}

\begin{abstract}
Highbush blueberry is a group of endemic species from North America. Its introduction to Belarusian Polesia is associated with transfer of cultivars of this group into an environment with a harsher climate. Adaptive capacity of highbush blueberry allowed its cultivars to adapt to the new environment, fully develop their fruits and complete their vegetation cycle. The property of the plants to fully utilize the time of their vegetation period manifested as shortening of the completion of the main phenophases due to the influence of the temperature factor. In an introduced environment the speed of the phenophases significantly depended on the peak day temperatures, which allowed the cultivars to successfully develop their fruits in an environment where they don't receive sufficient heat during the vegetation period, as well as to complete the vegetation cycle.
\end{abstract}

\section{Introduction}

There are no two places on Earth with identical climate, soil and other conditions. As such, any plant upon introduction finds itself in a new for it environmental conditions. By reacting to these conditions, the plant begins to adapt to them and change itself within its reaction norm. Adaptive capacity of the introduced plants is cumulative manifestation of their adaptive reaction to the limiting factors of the point of introduction.

Highbush blueberry is a group of endemic species growing along the Atlantic Coast in North America. Cultivars produced from North American blueberries were initially adapted to climate factors of that region. When introduced in Belarusian Polesia the cultivar is forced to adapt to the changes in environmental factors [1].

The goal of this research was assessment of the adaptive capacity of cultivars of highbush blueberry of different ripening periods in different environmental conditions when introduced to Belarusian Polesia.

\section{Materials and methods}

Three cultivars with different ripening periods were selected as the object of the research: early ripening Duke, mid-ripening Bluecrop and late ripening Elizabeth. Observations were

\footnotetext{
*Corresponding author: vaccinium@mail.ru
} 
conducted in Gantsevichi district, Brest region on a collection field of highbush blueberry of the industrial laboratory for introduction and technology of non-traditional berry plants of the Central Botanical Garden NAS of Belarus over the course of 9 years: from 2011 to 2019. The experiments were set up according to the methodology of Dospekhov B.A.[2].

As biological rhythms, specifically the change in speed and nature of the biological processes over time, are the most important form of adaptation of an organism to its environment, phenological rhythms of the researched cultivars were monitored. Phenological monitoring was conducted according to the methodology of I.D. Yurkevich et al. [3]. Calendar dates of occurrence of the main phenological phases and speed of their completion depending on the heat sum and fluctuations of the temperature factors during a given period were recorded. Observation data of the Gantsevichi weather station was used to calculate the heat sums, as well as to study the dynamics of the average, maximum and minimum daily temperatures, and their daily changes.

A similarly important criterion is the ability of a plant to fully develop its fruit in new climate conditions. Study of the fruiting peculiarities was conducted using the methodology of S.Ye. Korovin et al. [4]. The harvest was measured utilizing the weight method over multiple stages, as the fruits ripened, by weighing them and adding up the mass of the harvested fruits from each of the monitored plants, after which average indices were calculated for each cultivar.

Data processing was done using a personal computer with the help of Analysis ToolPak in Microsoft Excel application at a 95\% level of significance.

\section{Results and discussion}

Highbush blueberry occurs in North America along the Atlantic Coast from $29^{\circ} \mathrm{N}$ to $44^{\circ} \mathrm{N}$. In order to successfully finish fruiting, species of this group require no less than 150 days with temperature above $+10^{\circ} \mathrm{C}$. The vegetation period in the growing area of this group blueberry plants lasts from 155 to 235 days, the number of days with temperature above $0^{\circ} \mathrm{C}$ varies from 240 to 270 and more, absolute minimum winter temperatures in only two states (Maine and Ontario) rarely reach $-30^{\circ} \mathrm{C}$, and most often do not below the $-20^{\circ} \mathrm{C}$ mark. Sum of active temperatures varies from $2500^{\circ} \mathrm{C}$ to $3900^{\circ} \mathrm{C}$ and more, thermal time from $3000^{\circ} \mathrm{C}$ to $4400^{\circ} \mathrm{C}$.

Gntsevichi district is situated in southwest Belarus, roughly at latitude $52^{\circ} \mathrm{N}$, which is approximately $900 \mathrm{~km}$ further north than the northernmost place where blueberry occurs in North America. In addition, the area of introduction is situated deep within the continent and is characterized by a temperate continental climate, unlike the humid continental climate of North America in the growing area of highbush blueberry. Main climate characteristics: length og the vegetation period, number of days with temperature below $0^{\circ}$,

thermal time and sum of active temperatures during the monitoring period varied within the ranges comparable to similar indices in USA, although they were somewhat lower (table 1).

One of the mechanisms of the expression of the adaptation potential is the ability of a plant to make full use of the time during the vegetation period. As a rule, biological rhythms coincide in their periodicity with regular changes in ecological factors, such as temperature, duration of the daylight hours, etc. As a result of the monitoring, a significant variation in the calendar dates of beginning and duration of the phenological phases depending on meteorological conditions of the observation year (table 2,3) as well as on cultivar properties has been established.

In particular, mass flowering during the monitoring period was observed for the early ripening cultivar Duke during the period between April 30 and May 29 and with thermal time ranging from $350^{\circ} \mathrm{Cd}$ to $660^{\circ} \mathrm{Cd}$, for the mind-ripening cultivar Bluecrop - in the 
period between May 2 and May 23 and with thermal time from $370^{\circ} \mathrm{Cd}$ to $650^{\circ} \mathrm{Cd}$, and for the late ripening cultivar Elizabeth - from May 8 to May 26 and with thermal time from $470^{\circ} \mathrm{Cd}$ to $690^{\circ} \mathrm{Cd}$. The length of the flowering phenophase itself was 19 to 47 days for Duke, 16 to 48 days for Bluecrop and 23 to 48 days for Elizabeth.

Table 1. Climate situation of the Gantsevichi district during the research period

\begin{tabular}{|c|c|c|c|c|c|c|c|c|c|}
\hline Climate data by year & 2011 & 2012 & 2013 & 2014 & 2015 & 2016 & 2017 & 2018 & 2019 \\
\hline Days with temp. above $0^{\circ}$ & 232 & 230 & 238 & 236 & 268 & 248 & 267 & 224 & 254 \\
\hline Heat sum & 3115 & 3267 & 3180 & 3360 & 3260 & 3150 & 3105 & 3465 & 3405 \\
\hline $\begin{array}{c}\text { Sum of active temp. (above } \\
\left.10^{\circ} \mathrm{C}\right)\end{array}$ & 2720 & 2975 & 2660 & 2690 & 2690 & 2650 & 2380 & 3080 & 2995 \\
\hline $\begin{array}{c}\text { Duration of the vegetation } \\
\text { period, days }\end{array}$ & 163 & 186 & 159 & 140 & 160 & 159 & 140 & 175 & 189 \\
\hline
\end{tabular}

Table 2. Calendar dates of the beginning of the generative phenophases during the monitoring period

\begin{tabular}{|c|c|c|c|c|c|c|c|c|c|}
\hline \multicolumn{7}{|c|}{ Calendar dates of the generative phenophases by the observation year } \\
\hline $\begin{array}{c}\text { Pheno- } \\
\text { phase }\end{array}$ & \multicolumn{3}{|c|}{ Mass flowering } & \multicolumn{3}{c|}{ Mass blooming } & \multicolumn{3}{c|}{ Mass fruiting } \\
\hline Cultivar & Duke & $\begin{array}{c}\text { Blue- } \\
\text { crop }\end{array}$ & $\begin{array}{c}\text { Eliza- } \\
\text { beth }\end{array}$ & Duke & $\begin{array}{c}\text { Blue- } \\
\text { crop }\end{array}$ & $\begin{array}{c}\text { Eliza- } \\
\text { beth }\end{array}$ & Duke & $\begin{array}{c}\text { Blue- } \\
\text { crop }\end{array}$ & $\begin{array}{c}\text { Eliza- } \\
\text { beth }\end{array}$ \\
\hline 2011 & 29.05 & 23.05 & 26.05 & 30.05 & 29.05 & 31.05 & 25.07 & 25.07 & 23.08 \\
\hline 2012 & 12.05 & 12.05 & 16.05 & 16.05 & 15.05 & 24.05 & 15.07 & 10.08 & 25.08 \\
\hline 2013 & 17.05 & 19.05 & 19.05 & 21.05 & 23.05 & 24.05 & 15.07 & 1.08 & 30.08 \\
\hline 2014 & 4.05 & 3.05 & 13.05 & 14.05 & 20.05 & 20.05 & 16.07 & 20.07 & 20.08 \\
\hline 2015 & 23.05 & 23.05 & 26.05 & 25.05 & 30.05 & 28.05 & 4.08 & 15.08 & 1.09 \\
\hline 2016 & 11.05 & 17.05 & 24.05 & 20.05 & 20.05 & 30.05 & 15.07 & 25.07 & 5.09 \\
\hline 2017 & 19.05 & 19.05 & 21.05 & 26.05 & 26.05 & 31.05 & 7.08 & 17.08 & 15.09 \\
\hline 2018 & 30.04 & 2.05 & 8.05 & 8.05 & 11.05 & 15.05 & 20.07 & 27.07 & 14.08 \\
\hline 2019 & 8.05 & 20.05 & 21.05 & 17.05 & 24.05 & 25.05 & 25.07 & 10.08 & 2.09 \\
\hline
\end{tabular}

Table 3. Heat sum during the vegetation period before the beginning of the generative phenophases during the monitoring period

\begin{tabular}{|c|c|c|c|c|c|c|c|c|c|}
\hline \multicolumn{8}{|c|}{ Heat sum during the generative phenophases by the observation year } \\
\hline $\begin{array}{c}\text { Pheno- } \\
\text { phase }\end{array}$ & \multicolumn{2}{|c|}{ Mass flowering } & \multicolumn{3}{|c|}{ Mass blooming } & \multicolumn{3}{c|}{ Mass fruiting } \\
\hline Cultivar & Duke & $\begin{array}{c}\text { Blue- } \\
\text { crop }\end{array}$ & $\begin{array}{c}\text { Eliza- } \\
\text { beth }\end{array}$ & Duke & $\begin{array}{c}\text { Blue- } \\
\text { crop }\end{array}$ & $\begin{array}{c}\text { Eliza- } \\
\text { beth }\end{array}$ & Duke & $\begin{array}{c}\text { Blue- } \\
\text { crop }\end{array}$ & $\begin{array}{c}\text { Eliza- } \\
\text { beth }\end{array}$ \\
\hline 2011 & $660^{\circ}$ & $560^{\circ}$ & $615^{\circ}$ & $680^{\circ}$ & $660^{\circ}$ & $700^{\circ}$ & $1750^{\circ}$ & $1750^{\circ}$ & $2280^{\circ}$ \\
\hline 2012 & $455^{\circ}$ & $455^{\circ}$ & $500^{\circ}$ & $500^{\circ}$ & $490^{\circ}$ & $630^{\circ}$ & $1380^{\circ}$ & $1730^{\circ}$ & $1970^{\circ}$ \\
\hline 2013 & $470^{\circ}$ & $510^{\circ}$ & $510^{\circ}$ & $550^{\circ}$ & $585^{\circ}$ & $600^{\circ}$ & $1525^{\circ}$ & $1830^{\circ}$ & $2380^{\circ}$ \\
\hline 2014 & $485^{\circ}$ & $475^{\circ}$ & $590^{\circ}$ & $600^{\circ}$ & $595^{\circ}$ & $595^{\circ}$ & $1680^{\circ}$ & $1760^{\circ}$ & $2420^{\circ}$ \\
\hline 2015 & $650^{\circ}$ & $650^{\circ}$ & $690^{\circ}$ & $675^{\circ}$ & $750^{\circ}$ & $730^{\circ}$ & $1910^{\circ}$ & $2170^{\circ}$ & $2470^{\circ}$ \\
\hline 2016 & $500^{\circ}$ & $590^{\circ}$ & $670^{\circ}$ & $610^{\circ}$ & $610^{\circ}$ & $770^{\circ}$ & $1630^{\circ}$ & $1800^{\circ}$ & $2040^{\circ}$ \\
\hline 2017 & $560^{\circ}$ & $560^{\circ}$ & $575^{\circ}$ & $660^{\circ}$ & $660^{\circ}$ & $745^{\circ}$ & $1940^{\circ}$ & $2130^{\circ}$ & $2590^{\circ}$ \\
\hline 2018 & $350^{\circ}$ & $370^{\circ}$ & $470^{\circ}$ & $470^{\circ}$ & $525^{\circ}$ & $580^{\circ}$ & $1235^{\circ}$ & $1390^{\circ}$ & $1800^{\circ}$ \\
\hline 2019 & $420^{\circ}$ & $570^{\circ}$ & $590^{\circ}$ & $515^{\circ}$ & $640^{\circ}$ & $660^{\circ}$ & $1960^{\circ}$ & $2240^{\circ}$ & $2680^{\circ}$ \\
\hline
\end{tabular}

A similar situation was observed during the blooming phase. For example, mass blooming during the monitoring period was noted for the Duke cultivar from May 8 to May 30 with thermal time from $470^{\circ} \mathrm{Cd}$ to $680^{\circ} \mathrm{Cd}$, for Bluecrop - from May 11 to May 30 with 
thermal time from $490^{\circ} \mathrm{Cd}$ to $750^{\circ} \mathrm{Cd}$, for Elizabeth - from May 15 to May 31 with thermal time from $580^{\circ} \mathrm{Cd}$ to $770^{\circ} \mathrm{Cd}$. The length of the blooming phenophase varied from 19 to 30 days for Duke, from 17 to 30 days for Bluecrop, from 16 to 25 days for Elizabeth.

Even more significant divergence was observed in the fruiting period. Mass fruiting depending on the monitoring year was noted for the Duke cultivar in the interval from July 15 to August 7 with heat sum from $1235^{\circ} \mathrm{C}$ to $1960^{\circ} \mathrm{C}$, for the Bluecrop cultivar - from July 20 to August 17 with heat sum from $1390^{\circ} \mathrm{C}$ to $2240^{\circ} \mathrm{C}$, for the Elizabeth cultivar from August 14 to September 15 with heat sum from $1800^{\circ} \mathrm{C}$ to $2680^{\circ} \mathrm{C}$. The duration of this phonological phase also varied considerably with observation years, and was 29-54 days for Duke, 36-63 days for Bluecrop, 47-83 days for Elizabeth (tables 2, 3, 4)

Table 4. Lengths of the phenophases in the monitored cultivars of highbush blueberry

\begin{tabular}{|c|c|c|c|c|c|c|c|c|c|}
\hline \multirow{2}{*}{$\begin{array}{c}\text { Observation } \\
\text { year }\end{array}$} & \multicolumn{6}{|c|}{ Lengths of phenophases (days) in cultivars of highbush blueberry } \\
\cline { 2 - 11 } & Duke & $\begin{array}{c}\text { Blue- } \\
\text { crop }\end{array}$ & $\begin{array}{c}\text { Eliza- } \\
\text { beth }\end{array}$ & Duke & $\begin{array}{c}\text { Blue- } \\
\text { crop }\end{array}$ & $\begin{array}{c}\text { Eliza- } \\
\text { beth }\end{array}$ & Duke & $\begin{array}{c}\text { Blue- } \\
\text { crop }\end{array}$ & $\begin{array}{c}\text { Eliza- } \\
\text { beth }\end{array}$ \\
\hline 2011 & 19 & 16 & 23 & 19 & 17 & 24 & 39 & 36 & 56 \\
\hline 2012 & 30 & 28 & 26 & 25 & 24 & 21 & 54 & 63 & 83 \\
\hline 2013 & 25 & 26 & 28 & 21 & 19 & 20 & 48 & 53 & 80 \\
\hline 2014 & 35 & 33 & 30 & 27 & 25 & 17 & 34 & 63 & 38 \\
\hline 2015 & 37 & 47 & 39 & 30 & 30 & 24 & 36 & 40 & 67 \\
\hline 2016 & 47 & 48 & 48 & 21 & 18 & 16 & 35 & 48 & 53 \\
\hline 2017 & 27 & 31 & 31 & 22 & 22 & 25 & 29 & 50 & 59 \\
\hline 2018 & 26 & 25 & 29 & 21 & 20 & 19 & 30 & 42 & 47 \\
\hline 2019 & 37 & 25 & 27 & 29 & 20 & 25 & 42 & 63 & 73 \\
\hline
\end{tabular}

As can be seen from the data provided, occurrence of main phenophases in cultivars of highbush blueberry varies within a wide range of calendar dates and thermal times. The lengths of these phenophases also varies considerably. At the same time, if the data in tables 3 and 5 is to be analyzed, dependence of time of the beginning and speed of the completion of generative phenophases in blueberry cultivars on the number of warm days during that phenophase becomes apparent.

Table 5. Number of days with maximum temperature above $+20^{\circ} \mathrm{C}$ by 10 day intervals

\begin{tabular}{|c|c|c|c|c|c|c|c|c|c|c|c|c|c|c|c|c|c|c|}
\hline \multirow{3}{*}{$\begin{array}{c}\text { Obser- } \\
\text { vation } \\
\text { year }\end{array}$} & \multicolumn{18}{|c|}{ Number of days with maximum temperature above $+20^{\circ} \mathrm{C}$} \\
\hline & \multicolumn{3}{|c|}{ May } & \multicolumn{3}{|c|}{ June } & \multicolumn{3}{|c|}{ July } & \multicolumn{3}{|c|}{ August } & \multicolumn{3}{|c|}{ September } & \multicolumn{3}{|c|}{ October } \\
\hline & I & II & III & I & II & III & I & II & III & I & II & III & $\mathrm{I}$ & II & III & I & II & III \\
\hline 2011 & 2 & 7 & 9 & 10 & 8 & 8 & 6 & 8 & 10 & 10 & 10 & 9 & 6 & 7 & 5 & 2 & 1 & - \\
\hline 2012 & 6 & 5 & 9 & 4 & 8 & 8 & 10 & 8 & 11 & 9 & 7 & 9 & 6 & 5 & 2 & 2 & 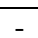 & - \\
\hline 2013 & 5 & 10 & 8 & 10 & 9 & 10 & 10 & 8 & 7 & 10 & 10 & 6 & 3 & 2 & $=$ & - & - & - \\
\hline 2014 & 4 & 4 & 8 & 9 & 5 & 4 & 10 & 9 & 11 & 10 & 10 & 5 & 5 & 6 & - & 2 & 3 & - \\
\hline 2015 & 2 & 2 & 6 & 10 & 10 & 7 & 10 & 9 & 11 & 10 & 10 & 11 & 4 & 6 & 4 & 2 & - & - \\
\hline 2016 & 7 & 3 & 11 & 8 & 8 & 10 & 10 & 10 & 10 & 10 & 7 & 11 & 10 & 6 & 1 & 1 & - & - \\
\hline 2017 & 3 & 3 & 10 & 7 & 8 & 9 & 7 & 10 & 11 & 10 & 10 & 6 & 4 & 4 & 1 & - & 1 & - \\
\hline 2018 & 9 & 7 & 10 & 9 & 10 & 7 & 6 & 10 & 11 & 10 & 10 & 10 & 10 & 8 & 1 & 1 & 3 & - \\
\hline 2019 & - & 7 & 10 & 10 & 10 & 10 & 5 & 7 & 11 & 9 & 10 & 11 & 10 & 3 & - & 1 & 5 & 2 \\
\hline
\end{tabular}

For example, in 2016 and 2017, at times of the longest duration of the flowering pase, the number of days with daytime temperature above $20^{\circ} \mathrm{C}$ was 3-7 in the $1^{\text {st }} 10$ day period of May, 3 in the $2^{\text {nd }}$, and only reached 10 days in the $3^{\text {rd }}$. A similar situation was observed in 2015 , when the number of days with temperature above $20^{\circ} \mathrm{C}$ by 10 day periods in May was 2, 2 and 6 days, and in 2012, with the number of warm days by 10 day periods in May being 6,5 and 9 , respectively. A similar situation could be observed during the blooming 
and fruiting phenophases. The more days with temperatures above $20^{\circ} \mathrm{C}$ those periods had, the faster the observed phonological phse was completed. And, conversely, with increased number of days with air temperature during daytime below $20^{\circ} \mathrm{C}$ the length of the phonological phases increased (table 4, 5).

Similarly, temperature indices of the vegetation period affected the crop yield of cultivated blueberry, analysis of wich has been prior [2, 3]. The more days with temperatures above $20^{\circ} \mathrm{C}$ there was during the periods of fruiting and initiation of flower buds, the faster the fruiting phase was was completed and the more flower buds were initiated during that period, wich posititively affected the volum of the harvest in the following year. Crop yield of early ripening, mid-ripening and late ripening cultivars all depended on this variable. Late ripening cultivars receive roughly half as many days with temperatures above $+20^{\circ} \mathrm{C}$ for the flower bud initiation period than and mid-ripening ones. And, accordingly, crop yield of late ripening cultivars was annually twice lower than for early and mid-ripening ones.

\section{Conclusion}

- cumulative manifestation of the adaptive reaction of highbush blueberry to limiting factors of the place of introduction is varying dates of the beginning and the speeds of the phenological phases, as well as significant differences in crop yield by year;

- lengths of individual phenophases in cultivars of highbush blueberry during the vegetation period are regulated by a whole range of climate factors, the most evident of which is the influence of the temperature factor;

- $\quad$ speeds of the phenophases significantly depend on maximum daily temperatures, which helps explain cultivars of highbush blueberry successfully developing their fruit in an environment with insufficient heat sum during the vegetation period;

- the influence of the temperature factor on the speed of phenophase completion and crop yield can be clearly observed, despite the genetically determined cultivar specifics of highbush blueberry.

\section{References}

1. T. V. Kurlovich, V. N. Bosak. Highbush Blueberry in Belarus (1998)

2. B. A. Dospekhov. Methodology of a Field Experiment (1985)

3. I. D. Yurkevich, D. S. Golod, E. P. Yaroshevich, Phenological Observations of Arboreal and Herbaceous Plants (1980)

4. S. Ye. Korovin, Z. Ye. Kuzmin, N. V. Trulevich, A. N. Shvetsov, Plant Relocation: Methodical Approach to Conducting Experiments (2004)

5. T. V. Kurlovich, Effect of length and thermal time of the growing season on blueberry production. Plant Diversity, State, Trends, Concept of Conservation: Report Theses of the All-Russian Conference Involving Foreign Scientists, Novosibirsk. (2020, September 30 - October 3)

6. T. Kurlovich, Effect of length and thermal time of the growing season on blueberry production, Plant Diversity: Status, Trends, Conservation Concept, September 21, (2020) 